\title{
PENDIDIKAN KARAKTER SISWA MELALUI IBADAH PUASA
}

\author{
Oki Dermawan \\ IAIN Raden Intan Lampung, Indonesia. \\ okidermawan76@yahoo.com
}

\begin{abstract}
Abstrak
Tulisan ini bertujuan untuk mengajarkan agama menggunakan nilai-nilai etika dengan contoh dari keluarga, sekolah dan masyarakat melalui praktek ibadah, seperti puasa bersama, membaca dan memahami kitab suci Al-Qur'an. Dalam bahasan ini digunakan metode pustaka dengan menggunakan deskripsi analisis. Puasa akan menyebabkan orang untuk memiliki prinsip yang kuat, kesabaran, dan keikhlasan tidak menyerah dan memiliki solidaritas dan saling mencintai. Ketika nilai dari sifat manusia kembali, maka nilai kesetaraan dan solidaritas akan mewarnai harihari siswa, puasa memiliki dimensi horizontal dengan kehidupan sosial yang kuat seperti amal, disajikan makanan anak-anak yatim, menjadi sabar ketika mendapat cobaan. Setelah bulan Ramadan, siswa diajarkan kegiatan Sunah puasa bersama dua kali seminggu yaitu Senin-Kamis. Ide Sunah puasa adalah menjadi pengaruh yang sangat efektif pada pembentukan karakter siswa.
\end{abstract}

Kata kunci: pendidikan karakter, puasa

\begin{abstract}
STUDENTS' CHARACTER EDUCATION TROUGH THE FASTING. This study examine how the way to teach a religion using ethical values by example from the family, school and community through the practice of worship, such as fasting together, reading and understanding the Qur'an. In the discussion, this study uses library
\end{abstract}


risearch throught analytical descriptive approach. Fasting will cause people to have strong principles, patience, and sincerity does not give up and have the solidarity and love each other. The result of this study show that the fasting is able to return, so at thet time. When the value of human nature came back, then the value of equality and solidarity will color the days of the student, fasting has a horizontal dimension with a strong social life such as charity, served meals the orphans, be patient in accepting the problem. After Ramadanin, students are taught the activities of Sunnah fasting together twice a week on Monday-Thursday. The idea of Sunnah fasting is to be very effective influence on the formation of student character.

Keywords: character education, fasting

\section{A. Pendahuluan}

Saat ini para pelajar sudah mulai meninggalkan akar budaya kita, seperti giat beribadah, gotong royong, saling membantu, tepo seliro, dan sikap-sikap positif lainnya, seperti jujur dan bertangung jawab. Sebagai bangsa yang religius, bangsa Indonesia belum mengaktulisasikan perilaku yang religius. "Kita belum bertuhan secara maknawi, tetapi baru secara ritual.

Pendidikan di sekolah memang tidak bisa lepas dari pendidikan di rumah. Orang tua ikut bertanggung jawab atas pendidikan anak-anaknya. Waktu anak bersama orang tua dan keluarga jauh lebih banyak dibandingkan dengan guru di sekolah. Artinya, orang tua seharusnya lebih mengetahui sifat-sifat anaknya. Sekolah seharusnya memiliki persatuan antara orang tua dan guru, dan mengadakan pertemuan rutin.

Sejak beberapa tahun yang lalu penyelenggara pendidikan di Indonesia baik sekolah negeri maupun swasta, menyelenggarakan pendidikan karakter. Pendidikan ini berkembang karena para pakar pendidikan di Indonesia mengakui bahwa sistem pendidikan yang telah ada, khususnya dalam bidang kepribadian (karakter) telah gagal dilakukan. Kegagalan ini setidaknya diperkuat oleh pendapat I Ketut Sumarta, seorang yang telah lama bergelut dalam dunia pendidikan. Dalam bukunya yang berjudul Pendidikan yang Memekarkan Rasa, ia mengatakan: "Pendidikan nasional kita cenderung hanya menonjolkan pembentukan kecerdasan berpikir dan menepikan penempatan kecerdasan rasa, kecerdasan budi, bahkan kecerdasan 
batin. Dari sini lahirlah manusia-manusia yang berotak pintar, manusia berprestasi secara kuantitatif akademik, namun tiada berkecerdasan budi sekaligus sangat tidak mandiri." Kutipan di atas menunjukkan bahwa telah terjadi ketidakpuasan atau cenderung terjadinya kegagalan dalam dunia pendidikan dalam rangka membentuk manusia dewasa dan berwatak mandiri. Kegagalan membentuk manusia dewasa dan berwatak mandiri ini kemudian diatasi atau diperkecil dengan melakukan program pendidikan karakter.

Seorang penyair Arab Syauqi Bey pernah berkata bahwa "Sesungguhnya kejayaan suatu umat (bangsa) terletak pada akhlak/ karakternya. Jika itu telah runtuh, maka runtuh pulalah bangsa itu." penyair Arab ini sangat relevan dengan hadis Rasulullah bahwa "Sesungguhnya aku diutus untuk menyempurnakan budi pekerti (HRAhmad)." Ciri dasar yang membedakan dengan makhluk lainnya (termasuk binatang) adalah akhlak.

Kurang berhasilnya sistem pendidikan membentuk sumber daya manusia dengan karakter yang tangguh, berbudi pekerti luhur, bertanggung jawab, berdisiplin, dan mandiri, terjadi hampir di semua lembaga pendidikan baik negeri maupun swasta. Lebih jauh upaya program pendidikan karakter sesuai dengan nilai-nilai budaya bangsa Indonesia terkesan tidak berjalan seperti yang diinginkan. Lembaga-lembaga pendidikan baik yang bersifat umum maupun yang berlandaskan nilai-nilai Islam berupaya sedapat mungkin menanamkan dan mengembangkan karakter siswanya sesuai dengan nilai-nilai universal yang berlaku. Ada yang beranggapan bahwa mendidik kepribadian siswa adalah tanggung jawab orang tua. Pendapat ini sebagian memang benar, tetapi sebagai sekolah juga mempunyai fungsi untuk mendidik. Pendidik sebagai orang tua kedua juga terpanggil untuk mendidik anak dalam perilaku dan bukan hanya mengajarkan berbagai pengetahuan.

Terdapat empat faktor yang melatarbelakangi penelitian ini, yaitu: perubahan dunia, perubahan sikap siswa, mentalitas bangsa yang buruk, dan krisis multidimensional. Masing-masing faktor tersebut akan dibahas lebih rinci sebagai berikut.

\section{Dunia yang sedang mengalami perubahan}

Ada pemahaman bahwa hidup dalam masa ini seringkali 
membingungkan, baik bagi orang tua maupun anak-anak. Ada banyak hal yang berubah di sekeliling kita dalam politik, sosial ekonomi, moral, dan spiritual. Di tengah perubahan itu tampak melemahnya penegakan disiplin dan peraturan, sehingga apa yang benar dan apa yang salah tidak jelas. Dengan kata lain, batas-batas moral menjadi kabur. Kekaburan ini menyebabkan memilih sesuatu yang benar dan tepat menjadi jauh lebih sukar, dan akibatnya salah pilih menjadi jauh lebih serius.

Penegakan disiplin, peraturan dan batas-batas moral menjadi jelas dalam kehidupan seorang siswa dapat dikembalikan dengan melakukan pembinaan secara sengaja dan terarah. Pembinaan tersebut dilakukan dengan dilaksanakannnya pendidikan karakter secara nyata, dalam hal ini penulis menawarkan melalui puasa berjamaah di sekolah.

\section{Sikap siswa yang berubah}

Selain kedua alasan di atas, alasan yang lebih penting adalah banyaknya keluhan ketika terjadi interaksi antara orang tua dan guru tentang siswa. Banyak orang tua melaporkan anaknya enggan pergi ke sekolah, anak takut maju ke depan kelas ketika mendapat giliran atau anak tidak ada kemauan untuk belajar. Guru menyatakan bahwa banyak siswa kurang menunjukkan kesungguhan dalam belajar dan kurang berusaha, terlambat datang, sering tidak membuat tugas, menyontek, kurang ramah, angkuh, meremehkan, bersikap kurang ajar, menentang dan berkecenderungan balas dendam, kurang tegar dan tangguh dalam menghadapi tekanan.

\section{Mentalitas Bangsa yang Buruk}

Indonesia memiliki modal atau kekuatan yang memadai untuk menjadi bangsa besar dan negara yang kuat. Modal itu antara lain: luas wilayah, jumlah penduduk, kekayaan alam, kekayaan budaya, kesatuan bahasa, ketaatan pada ajaran agama, dan sistem pemerintahan republik yang demokratis. Akan tetapi modal yang besar itu seakan tidak banyak berarti apabila mentalitas bangsa ini belum terbangun atau belum berubah ke arah yang lebih baik. Mentalitas bangsa Indonesia yang kurang kondusif atau menjadi penghambat kejayaan bangsa Indonesia menjadi bangsa maju antara lain: malas, tidak disiplin, suka melanggar aturan, ngaji pumpung, 
suka menerabas, dan nepotisme.

Selama mental sebuah bangsa tersebut tidak berubah, maka bangsa tersebut juga tidak akan mengalami perubahan dan akan tertinggal dengan bangsa-bangsa lain, meskipun bangsa tersebut sesungguhnya memiliki potensi dan modal yang besar. Allah dalam hal ini secara tegas mengatakan: "Sesungguhnya Allah tidak mengubah keadaan sesuatu kaum sehingga mereka mengubah keadaan yang ada pada diri mereka sendiri (QS. 13:11).

\section{Krisis multidimensional}

Berbagai permasalahan menimpa Bangsa Indonesia seperti masih adanya konflik sosial di berbagai tempat, sering mengedepankan cara kekerasan dalam menyelesaikan berbagai permasalahan, praktek korupsi yang semakin canggih dan massif, sering terjadi perkelahian antar pelajar, pelanggaran etika dan susila yang semakin vulgar, munculnya aliran yang dianggap sesat dan cara-cara penyelesaiannya yang cenderung menggunakan kekerasan, tindakan kejahatan yang mengancam ketenteraman dan keamanan, praktek demokrasi liberal yang ekstrem dalam berbagai aspek kehidupan sehingga bertabrakan dengan budaya dan nilai-nilai kepatutan sebagai bangsa timur dan bangsa yang religius.

Permasalahan yang serius juga terjadi di dunia pendidikan. Pelanggaran etika sosial dan susila serta kekerasan dalam berbagai bentuknya sering terjadi seperti: perkelahian antar pelajar, seks bebas, tindak pidana, sikap tidak etis terhadap guru, berbagai bentuk pelanggaran tata tertib sekolah, dan minimnya prestasi dan kejayaan yang dicapai para pelajar kita.

Permasalahan bangsa tersebut di atas semakin diperparah dengan tayangan telivisi yang sangat vulgar, tidak mengenal waktu tayang, dan diulang-ulang oleh hampir semua stasiun TV dan juga surat kabar. Peristiwa kriminal justru menjadi menu utama dan disiarkan diberbagai stasiun tv. Semboyan wartawan adalah "bad news is good news". Berita baik apabila ada unsur 'blood" dan "crowd".

Berbagai permasalahan tersebut diasumsikan bersumber dari krisis etika dan moral. Media yang paling ampuh untuk merubah mentalitas bangsa adalah lewat pendidikan dan keyakinan agama. Pendidikan yang mampu merubah mentalitas adalah pendidikan 
yang dilaksanakan dengan sungguh-sungguh dan sepenuh hati, bukan hanya sekedar formalitas atau kepura-puraan. Keyakinan agama juga besar pengaruhnya bagi mentalitas bangsa. Karena itu melalui pengamalan agama secara berjamaah seperti puasa sunnah mampu menanamkan keimanan, ibadah dan akhlakul karimah, niscaya akan menjadikan anak didik sebagai manusia terbaik, yaitu yang bermanfaat bagi orang lain melalui amal shalehnya.

Melakukan pendidikan karakter dengan religious approach merupakan sebuah usaha pembentukan manusia seutuhnya. Hal ini sesuai dengan UU No 20 Tahun 2003 Tentang Sistem Pendidikan Nasional pada Pasal 3, yang menyebutkan bahwa pendidikan nasional berfungsi mengembangkan kemampuan dan membentuk karakter serta peradaban bangsa yang bermartabat dalam rangka mencerdaskan kehidupan bangsa. Pendidikan nasional bertujuan untuk berkembangnya potensi peserta didik agar menjadi manusia yang beriman dan bertakwa kepada Tuhan Yang Maha Esa, berakhlak mulia, sehat, berilmu, cakap, kreatif, mandiri, dan menjadi warga negara yang demokratis serta bertanggung jawab.

\section{B. Pembahasan}

\section{Pendidikan Karakter}

Karakter berasal dari bahasa latin "kharakter", "kharassein", "kharax", dalam bahasa Inggris "character" dan Indonesia "karakter", Yunani "character" (dari charassein) yang berarti membuat tajam, membuat dalam. Dalam kamus Poerwadarminta, karakter diartikan tabiat, watak, sifat-sifat kejiwaan, akhlak atau budi pekerti yang membedakan seseorang dengan yang lain. Selanjutnya, karakter menurut Ryan dan Bohlin mengandung tiga unsur pokok yaitu mengetahui kebaikan (knowing the good), mencintai kebaikan (loving the good) dan melakukan kebaikan (doing the good) (Majid dan Dian Andayani, 2011: 11). Hal yang sama dengan pandangan ini adalah Thomas Lickona yang menyatakan bahwa pendidikan karakter yang baik, harus melibatkan bukan saja aspek "pengetahuan yang baik" tetapi juga "merasakan dengan baik" atau loving good (moral feeling), dan "perilaku yang baik". Jadi pendidikan karakter erat kaitannya dengan "habit" atau kebiasaan yang terus menerus dipraktikkan dan dilakukan. 
Karakter dapat juga diartikan sama dengan akhlak dan budi pekerti, sehingga karakter bangsa identik dengan akhlak bangsa atau budi pekerti bangsa. Bangsa yang berkarakter adalah bangsa yang berakhlak dan berbudi pekerti, sebaliknya bangsa yang tidak berkarakter adalah bangsa yang tidak atau kurang berakhlak atau tidak memiliki standar norma dan perilaku yang baik.

Dasar pembentukan karakter itu adalah nilai baik atau buruk. Nilai baik disimbolkan dengan nilai Malaikat dan nilai buruk disimbolkan dengan nilai Setan. Karakter manusia merupakan hasil tarik-menarik antara nilai baik dalam bentuk energi positif dan nilai buruk dalam bentuk energi negatif. Energi positif itu berupa nilainilai etis religius yang bersumber dari keyakinan kepada Tuhan, sedangkan energi negatif itu berupa nilai-nilai yang amoral yang bersumber dari (taghüt) Setan.

Nilai-nilai etis moral itu berfungsi sebagai sarana pemurnian, pensucian dan pembangkitan nilai-nilai kemanusiaan yang sejati (hati nurani). Energi positif itu berupa: Pertama, kekuatan spiritual. Kekuatan spiritrual itu berupa îmân, islâm, ihsân dan taqwa, yang berfungsi membimbing dan memberikan kekuatan kepada manusia untuk menggapai keagungan dan kemuliaan (ahsani taqwim); Kedua, kekuatan potensi manusia positif, berupa âqlus salîm (akal yang sehat), qalbun satim (hati yang sehat), qalbun munib (hati yang kembali, bersih, suci dari dosa) dan nafsul mutmainnah (jiwa yang tenang), yang kesemuanya itu merupakan modal insani atau sumber daya manusia yang memiliki kekuatan luar biasa. Ketiga, sikap dan perilaku etis. Sikap dan perilaku etis ini merupakan implementasi dari kekuatan spiritual dan kekuatan kepribadian manusia yang kemudian melahirkan konsep-konsep normatif tentang nilai-nilai budaya etis. Sikap dan perilaku etis itu meliputi: istiq̄mah (integritas), ihlass, jihād dan amal saleh.

Energi positif tersebut dalam perspektif individu akan melahirkan orang yang berkarakter, yaitu orang yang bertaqwa, memiliki integritas (nafs al-mutmainnah) dan beramal saleh. Aktualisasi orang yang berkualitas ini dalam hidup dan bekerja akan melahirkan akhlak budi pekerti yang luhur karena memiliki personality (integritas, komitmen dan dedikasi), capacity (kecakapan) dan competency yang bagus pula (professional). 
Kebalikan dari energi positif di atas adalah energi negatif. Energi negatif itu disimbolkan dengan kekuatan materialistik dan nilai-nilai (țăghu $t)$ nilai-nilai destruktif. Kalau nilainilai etis berfungsi sebagai sarana pemurnian, pensucian dan pembangkitan nilai-nilai kemanusiaan yang sejati (hati nurani), nilai-nilai material (țäghut) justru berfungsi sebaliknya yaitu pembusukan, dan penggelapan nilai-nilai kemanusiaan.

Hampir sama dengan energi positif, energi negatif terdiri dari: Pertama, kekuatan thaghut. Kekuatan țaghh $\bar{u} t$ itu berupa (kufr) kekafiran, (munäfiq) kemunafikan, (fasiq) kefasikan dan (syirik) kesyirikan yang kesemuanya itu merupakan kekuatan yang menjauhkan manusia dari makhluk etis dan kemanusiaannya yang hakiki (ahsani taqwim) menjadi makhluk yang serba material (asfala săfilin); Kedua, kekuatan kemanusiaan negatif, yaitu pikiran jahiliyah (pikiran sesat), qalbun marid (hati yang sakit, tidak merasa), qalbun mayyit (hati yang mati, tidak punya nurani) dan nafsu 'l-lawwämah (jiwa yang tercela) yang kesemuanya itu akan menjadikan manusia menghamba pada ilāh selain Allah berupa harta, sex dan kekuasaan (țăgut). Ketiga, sikap dan perilaku tidak etis. Sikap dan perilaku tidak etis ini merupakan implementasi dari kekuatan țagut dan kekuatan kemanusiaan negatif yang kemudian melahirkan konsep-konsep normatif tentang nilai-nilai budaya tidak etis (budaya busuk). Sikap dan perilaku tidak etis itu meliputi: takabur (congkak), hubb al-dunya (materialistik), dạalim (aniaya) dan amal sayyiāt (destruktif).

Energi negatif tersebut dalam perspektif individu akan melahirkan orang yang berkarakter buruk, yaitu orang yang puncak keburukannya meliputi syirk, nafs lawwämah dan 'amal al sayyiät (destruktif). Aktualisasi orang yang bermental thägüt ini dalam hidup dan bekerja akan melahirkan perilaku tercela, yaitu orang yang memiliki personality tidak bagus (hipokrit, penghianat dan pengecut) dan orang yang tidak mampu mendayagunakan kompetensi yang dimiliki.

\section{Pendidikan Karakter di Sekolah}

Berdasarkan fungsi dan tujuan pendidikan nasional, jelas bahwa pendidikan di setiap jenjang, harus diselenggarakan secara sistematis guna mencapai tujuan tersebut. Hal tersebut berkaitan 
dengan pembentukan karakter peserta didik sehingga mampu bersaing, beretika, bermoral, sopan santun dan berinteraksi dengan masyarakat. Berdasarkan penelitian di Harvard University Amerika Serikat (Akbar, 2000), ternyata kesuksesan seseorang tidak ditentukan semata-mata oleh pengetahuan dan kemampuan teknis (hard skill) saja, tetapi lebih oleh kemampuan mengelola diri dan orang lain (soft skill). Penelitian ini mengungkapkan, kesuksesan hanya ditentukan sekitar 20 persen oleh hard skill dan sisanya 80 persen oleh soft skill. Bahkan orang-orang tersukses di dunia bisa berhasil dikarenakan lebih banyak didukung kemampuan soft skill daripada hard skill. Hal ini mengisya-ratkan bahwa mutu pendidikan karakter peserta didik sangat penting untuk ditingkatkan.

Karakter merupakan nilai-nilai perilaku manusia yang berhubungan dengan Tuhan Yang Maha Esa, diri sendiri, sesama manusia, lingkungan, dan kebangsaan yang terwujud dalam pikiran, sikap, perasaan, perkataan, dan perbuatan berdasarkan norma-norma agama, hukum, tata krama, budaya, dan adat istiadat.

Puncak karakter seorang muslim adalah taqwa, dan indikator ketaqwaannya adalah terletak pada akhlaknya tujuan pendidikan yaitu manusia berkarakter taqwa yaitu manusia yang memiliki akhlak budi pekerti yang luhur. Karakter dibangun berdasarkan pemahaman tentang hakikat dan struktur kepribadian manusia secara integral. Sehingga manusia berkarakter taqwa adalah gambaran manusia ideal yaitu manusia yang memiliki kecerdasan spiritual (spiritual quotient). Kecerdasan spiritual inilah yang seharusnya paling ditekankan dalam pendidikan. Hal ini dilakukan dengan penanaman nilai-nilai etis religius melalui keteladanan dari keluarga, sekolah dan masyarakat, penguatan pengamalan peribadatan, menjalankan puasa sunnah, pembacaan dan penghayatan kitab suci Al-Qur'an, penciptaan lingkungan baik fisik maupun sosial yang kondusif.

Apabila spiritualitas anak sudah tertata, maka akan lebih mudah untuk menata aspek-aspek kepribadian lainnya. Maksudnya, kalau kecerdasan spiritual anak berhasil ditingkatkan, secara otomatis akan meningkatkan kecerdasan-kecerdasan lainnya seperti kecerdasan emosional (emotional quotient), kecerdasan memecahkan masalah (adversity quotient) dan kecerdasan intelektual (intellectual quotient). 
Inilah sebenarnya kunci mengapa aktifitas pendidikan yang berbasis agama lebih banyak berhasil dalam membentuk kepribadian siswa.

Pendidikan karakter adalah suatu sistem penanaman nilainilai karakter kepada warga sekolah yang meliputi komponen pengetahuan, kesadaran atau kemauan, dan tindakan untuk melaksanakan nilai-nilai tersebut, baik terhadap Tuhan Yang Maha Esa (Allah SWT), diri sendiri, sesama, lingkungan, maupun kebangsaan sehingga menjadi manusia insan kamil. Dalam pendidikan karakter di sekolah, semua komponen (stakeholders) harus dilibatkan, termasuk komponen-komponen pendidikan itu sendiri, yaitu isi kurikulum, proses pembelajaran dan penilaian, kualitas hubungan, penanganan atau pengelolaan mata pelajaran, pengelolaan sekolah, pelaksanaan aktivitas atau kegiatan kurikuler, pemberdayaan sarana prasarana, pembiayaan, dan etos kerja seluruh warga dan lingkungan sekolah.

Terlepas dari berbagai kekurangan dalam praktik pendidikan di Indonesia, apabila dilihat dari standar nasional pendidikan yang menjadi acuan pengembangan kurikulum (KTSP), dan implementasi pembelajaran dan penilaian di sekolah, tujuan pendidikan sebenarnya dapat dicapai dengan baik. Pembinaan karakter juga termasuk dalam materi yang harus diajarkan dan dikuasai serta direalisasikan oleh peserta didik dalam kehidupan sehari-hari. Permasalahannya, pendidikan karakter di sekolah selama ini baru menyentuh pada tingkatan pengenalan norma atau nilai-nilai, dan belum pada tingkatan internalisasi dan tindakan nyata dalam kehidupan seharihari.

Sebagai upaya untuk meningkatkan kesesuaian dan mutu pendidikan karakter, Kementerian Pendidikan Nasional mengembangkan grand design pendidikan karakter untuk setiap jalur, jenjang, dan jenis satuan pendidikan. Grand design menjadi rujukan konseptual dan operasional pengembangan, pelaksanaan, dan penilaian pada setiap jalur dan jenjang pendidikan. Konfigurasi karakter dalam konteks totalitas proses psikologis dan sosialkultural tersebut dikelompokan dalam: Olah Hati (Spiritual and emotional development), Olah Pikir (intellectual development), Olah Raga dan Kinestetik (Physical and kinestetic development), dan Olah Rasa dan Karsa (Affective and Creativity development). Pengembangan dan implementasi pendidikan karakter perlu dilakukan dengan mengacu 
pada grand design tersebut.

Menurut UU No 20 Tahun 2003 Tentang Sistem Pendidikan Nasional pada Pasal 13 Ayat 1 menyebutkan bahwa Jalur pendidikan terdiri atas pendidikan formal, nonformal, dan informal yang dapat saling melengkapi dan memperkaya. Pendidikan informal adalah jalur pendidikan keluarga dan lingkungan. Pendidikan informal sesungguhnya memiliki peran dan kontribusi yang sangat besar dalam keberhasilan pendidikan. Peserta didik mengikuti pendidikan di sekolah hanya sekitar 7 jam per hari, atau kurang dari 30\%. Selebihnya (70\%), peserta didik berada dalam keluarga dan lingkungan sekitarnya. Jika dilihat dari aspek kuantitas waktu, pendidikan di sekolah berkontribusi hanya sebesar 30\% terhadap hasil pendidikan peserta didik.

Selama ini, pendidikan informal terutama dalam lingkungan keluarga belum memberikan kontribusi berarti dalam mendukung pencapaian kompetensi dan pembentukan karakter peserta didik. Kesibukan dan aktivitas kerja orang tua yang relatif tinggi, kurangnya pemahaman orang tua dalam mendidik anak di lingkungan keluarga, pengaruh pergaulan di lingkungan sekitar, dan pengaruh media elektronik ditengarai bisa berpengaruh negatif terhadap perkembangan dan pencapaian hasil belajar peserta didik. Salah satu alternatif untuk mengatasi permasalahan tersebut adalah melalui pendidikan karakter terpadu, yaitu memadukan dan mengoptimalkan kegiatan pendidikan informal lingkungan keluarga dengan pendidikan formal di sekolah. Dalam hal ini, waktu belajar peserta didik di sekolah perlu dioptimalkan agar peningkatan mutu hasil belajar dapat dicapai, terutama dalam pembentukan karakter peserta didik.

Pendidikan karakter dapat diintegrasikan dalam pembelajaran pada setiap mata pelajaran. Materi pembelajaran yang berkaitan dengan norma atau nilai-nilai pada setiap mata pelajaran perlu dikembangkan, dieksplisitkan, dikaitkan dengan konteks kehidupan sehari-hari. Dengan demikian, pembelajaran nilai-nilai karakter tidak hanya pada tataran kognitif, tetapi menyentuh pada internalisasi, dan pengamalan nyata dalam kehidupan peserta didik sehari-hari di masyarakat. 
Kegiatan ekstra kurikuler yang selama ini diselenggarakan sekolah merupakan salah satu media yang potensial untuk pembinaan karakter dan peningkatan mutu akademik peserta didik. Kegiatan Ekstra Kurikuler merupakan kegiatan pendidikan di luar mata pelajaran untuk membantu pengembangan peserta didik sesuai dengan kebutuhan, potensi, bakat, dan minat mereka melalui kegiatan yang secara khusus diselenggarakan oleh pendidik dan atau tenaga kependidikan yang berkemampuan dan berkewenangan di sekolah. Melalui kegiatan ekstra kurikuler diharapkan dapat mengembangkan kemampuan dan rasa tanggung jawab sosial, serta potensi dan prestasi peserta didik.

Kegiatan berpuasa berjamaah pada bulan Ramadhan memiliki kelebihan ibadah lainnya dalam Islam karena sifatnya yang pribadi dan tersembunyi alias tidak terlihat oleh pandangan kasat manusia. Allah dalam sebuah hadis qudsi seperti yang tercantum dalam kitab Bukhari dan Muslim berfirman bahwa puasa adalah milik Nya yang pribadi dan Ia pun akan memberikan pahala secara spesial dan pribadi kepada hamba-hambanya yang diterima amal ibadah puasanya. "Puasa itu untuk-Ku, karena itu Akulah yang akan memberi ganjaraannya langsung!” (Bihar al-Anwaar 96: 255).

Ketua Umum PBNU KH Said Aqil Siraj dalam tulisannya di sebuah media massa. Kiai Said Aqil mengatakan secara kebangsaan Indonesia, puasa merupakan momentum untuk pembetukan karakter bangsa. Puasa akan melahirkan manusia-manusia yang memiliki prinsip tangguh, kesabaran, keiklasan dan tidak pantang menyerah serta memiliki solidaritas dan saling mengasihi satu sama lain. Prinsip itu saat ini terkesan luntur (bahkan menghilang) di sebagian besar masyarakat Indonesia.

Moment Ramadhan dapat pula menjadi sebuah agenda sekolah untuk melakukan pembinaan karakter, dengan media puasa ini, siswa diharapkan dapat ingat dan mau kembali kepada jati dirinya yang suci dan luhur dengan hadirnya kembali nilai-nilai kemanusian yang arif dan bijak. Ketika nilai fitrah manusia tersebut muncul kembali, maka nilai persamaan dan solidaritas atas penderitaan sesama makhluk hidup akan dapat hadir kembali mewarnai hari-hari anak, seiring nilai-nilai yang diajarkan dalam media puasa. Jika kita 
merenung dan mengkaji literatur Islam, dimensi kemanusiaan dan sosial dalam puasa sebenarnya sangat kental.

Puasa bulan Ramadhan punya maksud dan nilai yang sangat mulia pada pembentukan karakter siswa yang shaleh. Puasa memiliki dimensi garis horisontal yang kental dengan nuansa kehidupan sosial seperti berderma, menyantuni orang dua $\bar{a} f \bar{a}$, sabar dalam menerima cobaan. Karena barometer kebajikan bagi Allah bukan diukur dari banyaknya interaksi pribadi hamba kepadaNya akan tetapi kebajikan yang bersifat holistik, yang dapat menjiwainya dalam kehidupan sosial. Puasa sebenarnya sarat dengan pesan etika kesalehan sosial yang sangat tinggi, seperti pengendalian diri, disiplin, kejujuran, kesabaran, solidaritas dan saling tolongmenolong. Ini merupakan sebuah potret yang mengarah kepada eratnya keshalihan pribadi dengan keshalihan sosial, kepekaan sosial ini akan kita temukan dengan gamblang saat orang yang berpuasa diperintahkan mengeluarkan zakat fitrah di penghujung akhir puasanya sebagai media penyempurna ibadah puasanya.

Sangat tepat kiranya jika moment puasa Ramadhan dapat diteruskan di sekolah-sekolah setelah bulan Ramadhan dalam membentuk karakter siswanya melalui kegiatan puasa sunnah berjamaah dua kali dalam seminggu, atau memberikan kebebasan kepada siswa bermusyawah menentukan berapa kali dalam seminggu atau setiap bulannya diadakan puasa sunnah berjamaah, ide puasa sunnah berjamaah ini insya Allah akan berpengaruh terhadap karakter siswa seperti kejujuran, kesalehan, pengendalian diri dan disiplin mereka dalam kegiatan proses belajar mengajar maupun dalam kehidupan sehari-hari.

Pendidikan karakter di sekolah juga sangat terkait dengan manajemen atau pengelolaan sekolah. Pengelolaan yang dimaksud adalah bagaimana pendidikan karakter direncanakan, dilaksanakan, dan dikendalikan dalam kegiatan-kegiatan pendidikan di sekolah secara memadai. Pengelolaan tersebut antara lain meliputi, nilainilai yang perlu ditanamkan, muatan kurikulum, pembelajaran, penilaian, pendidik dan tenaga kependidikan, dan komponen terkait lainnya. Dengan demikian, pimpinan sekolah merupakan penentu efektif tidaknya dalam pendidikan karakter di sekolah. Kegiatan puasa 
sunnah berjamaah jika bukan berasal dari pimpinan, tentulah tidak akan dapat menyentuh seluruh warga sekolah, sebagai contoh, jika dianjurkan oleh seorang guru agama saja tentu berbeda efeknya jika dibandingkan dengan diinstruksikan oleh kepala sekolah.

Menurut Mochtar Buchori (2007), pendidikan karakter seharusnya membawa peserta didik ke pengenalan nilai secara kognitif, penghayatan nilai secara afektif, dan akhirnya ke pengamalan nilai secara nyata. Permasalahan pendidikan karakter yang selama ini dikarenakan pengalaman/pengamalan nilai secara nyata seperti beribadah berjamaah layaaknya shalat, puasa, bersedekah, belum diterapkan dilembaga pendidikan kita.

Pendidikan karakter bertujuan untuk meningkatkan mutu penyelenggaraan dan hasil pendidikan di sekolah yang mengarah pada pencapaian pembentukan karakter dan akhlak mulia peserta didik secara utuh, terpadu, dan seimbang, sesuai standar kompetensi lulusan. Melalui pendidikan karakter diharapkan peserta didik mampu secara mandiri meningkatkan dan menggunakan pengetahuannya, mengkaji dan menginternalisasi serta mempersonalisasi nilai-nilai karakter dan akhlak mulia sehingga terwujud dalam perilaku seharihari.

Pendidikan karakter pada tingkatan institusi mengarah pada pembentukan budaya sekolah, yaitu nilai-nilai yang melandasi perilaku, tradisi, kebiasaan keseharian, dan simbol-simbol yang dipraktikkan oleh semua warga sekolah, dan masyarakat sekitar sekolah. Budaya sekolah merupakan ciri khas, karakter atau watak, dan citra sekolah tersebut di mata masyarakat luas.

Melalui pendidikan karakter ini diharapkan lulusannya memiliki keimanan dan ketaqwaan kepada Tuhan Yang Maha Esa, berakhlak mulia, berkarakter mulia, kompetensi akademik yang utuh dan terpadu, sekaligus memiliki kepribadian yang baik sesuai normanorma dan budaya Indonesia. Pada tataran yang lebih luas, pendidikan karakter nantinya diharapkan menjadi budaya sekolah.

Keberhasilan program pendidikan karakter dapat diketahui melalui pencapaian indikator oleh peserta didik sebagaimana tercantum dalam Standar Kompetensi Lulusan, yang antara lain meliputi sebagai berikut: 
a. Mengamalkan ajaran agama yang dianut sesuai dengan tahap perkembangan;

b. Memahami kekurangan dan kelebihan diri sendiri;

c. Menunjukkan sikap percaya diri;

d. Mematuhi aturan-aturan sosial yang berlaku dalam lingkungan yang lebih luas;

e. Menghargai keberagaman agama, budaya, suku, ras, dan golongan sosial ekonomi dalam lingkup nasional;

f. Mencari dan menerapkan informasi dari lingkungan sekitar dan sumber-sumber lain secara logis, kritis, dan kreatif;

g. Menunjukkan kemampuan berpikir logis, kritis, kreatif, dan inovatif;

h. Menunjukkan kemampuan belajar secara mandiri sesuai dengan potensi yang dimilikinya;

i. Menunjukkan kemampuan menganalisis dan memecahkan masalah dalam kehidupan sehari-hari;

j. Mendeskripsikan gejala alam dan sosial;

k. Memanfaatkan lingkungan secara bertanggung jawab;

1. Menerapkan nilai-nilai kebersamaan dalam kehidupan bermasyarakat, berbangsa, dan bernegara demi terwujudnya persatuan dalam negara kesatuan Republik Indonesia;

m. Menghargai karya seni dan budaya nasional;

n. Menghargai tugas pekerjaan dan memiliki kemampuan untuk berkarya;

o. Menerapkan hidup bersih, sehat, bugar, aman, dan memanfaatkan waktu luang dengan baik;

p. Berkomunikasi dan berinteraksi secara efektif dan santun;

q. Memahami hak dan kewajiban diri dan orang lain dalam pergaulan di masyarakat; Menghargai adanya perbedaan pendapat;

r. Menunjukkan kegemaran membaca dan menulis naskah pendek sederhana.

Pendidikan karakter juga berarti melakukan usaha sungguhsungguh, sitematik dan berkelanjutan untuk membangkitkan dan menguatkan kesadaran serta keyakinan semua orang Indonesia bahwa tidak akan ada masa depan yang lebih baik tanpa membangun dan menguatkan karakter rakyat Indonesia, yakni dengan 
kejujuran, disiplin diri, kegigihan, semangat belajar yang tinggi, mengembangkan rasa tanggung jawab, memupuk persatuan di tengah-tengah kebinekaan, semangat berkontribusi bagi kemajuan bersama, serta rasa percaya diri dan optimisme. Inilah tantangan kita bangsa Indonesia. Theodore Roosevelt mengatakan: "To educate a person in mind and not in morals is to educate a menace to society" (Mendidik seseorang dalam aspek kecerdasan otak dan bukan aspek moral adalah ancaman marabahaya kepada masyarakat.

\section{Simpulan}

Kecerdasan spiritual seharusnya paling ditekankan dalam pendidikan. Hal ini dilakukan dengan penanaman nilai-nilai etis religius melalui keteladanan dari keluarga, sekolah dan masyarakat melalui penguatan pengamalan peribadatan, seperti menjalankan puasa berjamaah, pembacaan dan penghayatan kitab suci Al-Qur'an, penciptaan lingkungan baik fisik maupun sosial yang kondusif. Apabila spiritualitas anak sudah tertata, maka akan lebih mudah untuk menata aspek-aspek kepribadian lainnya.

Puasa berjamaah pada bulan Ramadhan merupakan momentum untuk pembetukan karakter bangsa. Puasa akan melahirkan manusia-manusia yang memiliki prinsip tangguh, kesabaran, keiklasan dan tidak pantang menyerah serta memiliki solidaritas dan saling mengasihi satu sama lain. Prinsip itu saat ini terkesan luntur. Moment Ramadhan dapat pula menjadi sebuah agenda sekolah untuk melakukan pembinaan karakter, dengan media puasa ini, siswa diharapkan dapat ingat dan mau kembali kepada jati dirinya yang suci dan luhur dengan hadirnya kembali nilai-nilai kemanusian yang arif dan bijak. Ketika nilai fitrah manusia tersebut muncul kembali, maka nilai persamaan dan solidaritas akan mewarnai hari-hari anak, dan nilai yang sangat mulia pada pembentukan karakter siswa yang shaleh.

Puasa memiliki dimensi garis horisontal yang kental dengan nuansa kehidupan sosial seperti berderma, menyantuni orang dhuafa, sabar dalam menerima cobaan. Sangat tepat kiranya jika moment puasa Ramadhan dapat diteruskan di sekolah-sekolah setelah bulan Ramadhan dalam membentuk karakter siswanya melalui kegiatan 
puasa sunnah berjamaah dua kali dalam seminggu senin-kamis, atau memberikan kebebasan kepada siswa bermusyawah menentukan berapa kali dalam seminggu atau setiap bulannya diadakan puasa sunnah berjamaah, ide puasa sunnah berjamaah ini insya Allah akan sangat efektif pengaruhnya terhadap pembentukan karakter siswa. 
Oki Dermawan

\section{DAFTAR PUSTAKA}

Akbar, Ali Ibrahim. 2000. Pendidikan Karakter. Rajawali: Jakarta.

Albertus, Doni Koesoema. 2007. Pendidikan Karakter: Strategi Mendidik Anak di Zaman Global. Jakarta: PT. Grasindo. - 2009. Pendidikan Karakter Di Zaman Keblinger, Mengembangkan Visi Guru Sebagai Pelaku Perubahan Dan Pendidik karakter .Jakarta: PT.Grasindo. . 2007. Tiga Matra Pendidikan, BASIS, Edisi Juli Agustus. .2007. Pendidikan Karakter Kompas. Pebruari.

Arikunto, Suharsimi. 2006 .Prosedur Penelitian; Suatu Pendekatan Praktik, Jakarta: Rineka Cipta.

Basari, Hasan, Bernhard Dahm. 1987. Sukarno dan perjuangan kemerdekaan, Jakarta: LP3ES. Judul asli: Sukarno and the struggle for Indonesia

Buchori, Mochtar. 2007. Evaluasi Pendidikan di Indonesia. Jakarta: Jakarta Press.

Gunawan, Iwan. 2007. Pendidikan Karakter; Suatu Keharusan. Kompas, November.

Hidayatullah, Furqon. 2010. Pendidikan Karakter: Membangun Peradaban Bangsa. Surakarta: UNS Press\&Yuma Pustaka.

Koentjaraningrat. 2002. Kebudayaan Mentalitas dan Pembangunan, Jakarta: Gramedia.

Majid, Ahmad dan Dian Andayani. 2008. Pendidikan Karakter Perspektif Islam. Bandung: Rosda.

Q-Anees, Bambang dan Adang Hambali. 2008. Pendidikan Karakter Berbasis Al Quran. Bandung: Simbiosa Rekatama Media.

Sjarkawi. 2006. Pembentukan Kepribadian Anak. Peran Moral, Intelektual, Emosional Dan Sosial Sebagai wujud Integritas Membangun Jati Diri. Jakarta: PTBumi Aksara.

Suryabrata, Sumadi. Psikologi Kepribadian. Jakarta: PT. Raja Grafindo Persada, 2002.

Tobroni. 2008. Pendidikan Islam, Paradigma Teologis, Filosofis dan 
Pendidikan Karakter Siswa Melalui Ibadah Puasa

Spiritualitas, Malang: UMM Press.

. 2010. The Spiritual Leadership, Mengefektifkan Organisasi Noble Industri Melalui Prinsip-Prinsip Spiritual Etis, Malang: UMM Press.

Zuhriah, Nurul. 2008. Pendidikan Moral Dan Budi Pekerti, Jakarta: PT.Bumi Aksara. 
Oki Dermawan

halaman ini bukan sengaja dikosongkan 